\title{
REVIEW FAKTOR DETERMINAN KERAGAMAN KONSUMSI PANGAN
}

\author{
(Review on Determinant Factors of Dietary Diversity)
}

Hardinsyah $^{1}$

\begin{abstract}
Index of food intake diversity or dietary diversity reflects the nutritional quality of the diet; and it is associated with nutritional health outcomes. Understanding factors determine index of dietary diversity is important for improving nutritional-health status of the people. However, no studies have been done to capture completely the determinant factors of dietary diversity. This journal article is intended to review the determinants factor of dietary diversity from studies done in both develop and developing countries at individual and household levels. The results show that four studies analyzed the food data at individual level and the other four studies analyzed the food data at household level; and most of the studies were done in USA. Method of dietary diversity measurement and its statistical analysis varies among the studies. A few dietary diversity studies have investigated particular determinant factors with attention given to assessing nutrition knowledge and socio-demographic factors; and the others on economic and ecological factors. The present review suggested that the determinant factors of dietary diversity are nutrition knowledge, food preference, household size and composition, food availability and ecological factors, time availability for food preparation, and food purchasing power e.g. income, food expenditure and food prices. Based on this review a comprehensive conceptual framework and model of the determinant factors of dietary diversity could be developed.
\end{abstract}

Keywords: determinant factors, dietary diversity,

\section{PENDAHULUAN}

\section{Latar Belakang}

Konsep keragaman konsumsi pangan untuk hidup sehat telah berkembang sejak abad ke-2 Sebelum Masehi di zaman Cina kuno. Pada zaman tersebut, makanan yang dianjur- kan adalah yang terdiri dari lima jenis biji-bijian, lima jenis pangan hewani, lima jenis buah dan lima jenis sayur, dan makanan atau minuman lain yang enak aroma dan rasanya (Zhi-chien, 1993).

Perkembangan IImu Gizi sekitar seabad Ialu tentang identifikasi dan manfaat berbagai komponen karbohidrat, komponen lemak dan komponen protein melahirkan konsep ilmiah tentang keragaman konsumsi pangan yang sesuai zamannya. Pada masa tersebut keragaman konsumsi pangan dimaknai sebagai keragaman jenis pangan sumber karbohidat, jenis pangan sumber lemak dan jenis pangan sumber protein. Kemudian sejalan dengan penemuan berbagai vitamin, konsep ilmiah keragaman konsumsi pangan berkembang menjadi keragaman konsumsi pangan yang terdiri dari

\footnotetext{
${ }^{1}$ Guru Besar pada Departemen Gizi Masyarakat, Fakultas Ekologi Manusia (FEMA) IPB
}

jenis-jenis pangan dari lima kelompok pangan utama, yaitu pangan sumber energi, pangan sumber protein, buah dan sayur (Hardinsyah, 1996).

Berbagai penelitian telah menganalisis situasi keragaman konsumsi pangan dan manfaat mengonsumsi anekaragam pangan bagi pemenuhan kebutuhan gizi dan perbaikan kualitas gizi makanan (Hardinsyah \& Heywood 1993). Selain itu ada pula penelitian tentang manfaat mengonsumsi anekaragam makanan bagi kesehatan dan hasilnya menunjukkan bahwa skor keragaman konsumsi pangan yang tinggi mengurangi risiko berbagai jenis penyakit tidak menular (Hardinsyah \& Mark, 1996; Moore et al., 2002) dan memperpanjang usia harapan hidup atau mengurangi risiko kematian (Kant et al., 1993; Trichopoulou et al., 1996).

Walau demikian, penelitian yang mengungkap tentang faktor determinan keragaman konsumsi pangan penduduk baik di negara maju maupun di negara sedang berkembang sangat terbatas. Sementara informasi tentang faktor-faktor yang menjadi determinan keragaman konsumsi pangan diperlukan bagi pembuat kebijakan dan pengelola program pangan dan gizi guna menetapkan kebijakan dan program yang mendorong peningkatan keragaman 
konsumsi pangan untuk percepatan perbaikan gizi dan kesehatan masyarakat (Hardinsyah, 1996).

Selain itu produsen pangan atau pimpinan industri pangan juga memerlukan informasi tertang hal ini agar bisa membuat analisis kecenderungan permintaan pangan dan arah pengembangan produk industri pangan.

Berbadasarkan hal-hal tersebut maka review tentang berbagai faktor yang mempengaruhi keragaman konsumsi pangan dipandang perlu untuk dilakukan.

\section{$\underline{\text { Tujuan }}$}

Tujuan review ini adalah untuk membuat tinjauan dan kesimpulan dari studi-studi yang telah dilakukan sebelumnya tentang faktorfaktor menjadi determinan keragaman konsumsi pangan penduduk.

\section{METODE}

Review ini dilakukan dengan mengumpulkan pustaka dari berbagai publikasi atau artikel berbahasa Inggris dan Indonesia sejak tahun 1970-an tentang faktor yang berhubungan atau mempengaruhi keragaman konsumsi pangan dengan keywords food diversification, food diversity, dietary diversity. Jumlah artikel yang diperoleh diperkirakan underestimate karena tidak mencakup publikasi atau artikel selain bahasa Inggris dan Indonesia.

Ada tujuh studi yang mengungkap peubah yang berhubungan atau peubah yang mempengaruhi (determinan) keragaman konsumsi pangan. Faktor determinan keragaman konsumsi pangan yang dikaji mencakup faktor pengetahuan gizi, sosio demografi dan ekonomi.

Berkaitan dengan sampel, tiga (Lee \& Brown, 1989; Lee, 1987; Hardinsyah, 1996) dari tujuh penelitian tersebut mengkaji keragaman konsumsi pangan keluarga atau rumahtangga, sedangkan penelitian lainnya mengkaji di tingkat individu. Dua penelitian menganalisis faktor determinan keragaman konsumsi pangan pada anak-anak, yaitu penelitian Caliendo et al. (1977) di USA dan Dewey (1981) di Mexico. Dua penelitian dilakukan di negara berkembang, yaitu penelitian yang dilakukan oleh Dewey (1981) di Meksiko dan Hardinsyah (1996) di Indonesia.

Sehubungan dengan jumlah penelitian yang sedikit dan untuk mempertimbangkan faktor-faktor lain yang diduga sebagai determinan keragaman konsumsi pangan, review ini tidak hanya tergantung pada tujuh studi tersebut, tapi juga berbagai penelitian lain yang terkait.

Selanjutnya artikel tersebut disarikan dalam suatu tabel untuk membandingkan secara ringkas tentang ukuran contoh dan lokasi studi, metode pengumpulan data dan pengukuran keragaman konsumsi pangan, metode analisis statistika, faktor determinan yang dianalisis dan hasil analisisnya.

Penelitian tersebut menerapkan ukuran keragaman konsumsi pangan yang bervariasi, bahkan sebagian menurut Hardinsyah (1996) mempunyai validitas yang rendah, dikaitkan dengan kualitas gizi makanan, seperti skor keragaman Konsumsi Pangan Sederhana (SKKS), Indeks Dewey, Indeks Shannon, dan Indeks Harfindahl.

\section{HASIL DAN PEMBAHASAN}

Rangkuman hasil review penelitian tentang faktor determinan keragaman konsumsi pangan disajikan secara ringkas pada Tabel 1 . Beberapa penelitian menganalisis faktor sosial-demografi dan ekonomi dalam hubungannya dengan keragaman konsumsi pangan. Sangat terbatas penelitian yang menganalisis faktor pengetahuan gizi.

\section{Pengetahuan Gizi}

Caliendo (1977) merupakan peneliti pertama yang mengkaji hubungan antara pengetahuan gizi dan skor keragaman konsumsi pangan (Tabel 1). Penelitian ini membuktikan bahwa keragaman pangan pada balita berkorelasi positif secara signifikan dengan pengetahuan gizi ibunya $(r=0.28)$. Kelemahan penelitian ini adalah menggunakan analisis hubungan peubah berpasangan (bivariate analysis), bukan multivariate analysis yang mempertimbangkan berbagai faktor pengganggu (con founding factors), dan menggunakan ukuran keragaman konsumsi pangan yang sederhana, yaitu simple food diversity score.

Meski memiliki kelemahan, hasil penelitian tersebut sejalan dengan dugaan bahwa ada hubungan antara pengetahuan gizi ibu dengan keragaman konsumsi pangan anak balitanya. Beberapa hasil penelitian menunjukkan bahwa makin tinggi tingkat pengetahuan gizi seseorang maka perilaku gizinya juga akan makin baik (Burns et al., 1988; Wandel, 1994). 
Tabel 1. Beberapa Penelitian mengenai Analisis Faktor Determinan Keragaman Konsumsi Pangan

\begin{tabular}{|c|c|c|c|c|c|c|c|}
\hline No & Sumber & $\begin{array}{l}\text { Sampel dan } \\
\text { Tempat }\end{array}$ & $\begin{array}{c}\text { Data } \\
\text { Pangan }\end{array}$ & \begin{tabular}{|c|} 
Ukuran Keragaman \\
Pangan
\end{tabular} & Analisis & Determinan yang diduga & Hasil( $^{\text {b) }}$ \\
\hline 1 & $\begin{array}{l}\text { Schorr } \\
\text { et al. } \\
\text { (1972) }\end{array}$ & $\begin{array}{l}118 \text { pelajar, } \\
\text { Wilayah pedesaan, } \\
\text { NY, USA }\end{array}$ & $\begin{array}{l}\text { Record } \\
\text { konsumsi } \\
\text { (3 hari) }\end{array}$ & SFD & $\begin{array}{r}\text { Analisis/ } \\
\text { korelasi } \\
\text { bivariat }\end{array}$ & $\begin{array}{l}\text { Umur } \\
\text { J enis kelamin } \\
\text { Ukuran Rumahtangga } \\
\text { Pendidikan ibu } \\
\text { Status pekerjaan ibu }\end{array}$ & $\begin{array}{l}\mathrm{Ns} \\
\mathrm{Ns} \\
\mathrm{Ns} \\
\mathrm{S}(0.15) \\
\mathrm{S}(0.22)\end{array}$ \\
\hline 2 & $\begin{array}{l}\text { Caliendo } \\
\text { et al. } \\
\text { (1977) }\end{array}$ & $\begin{array}{l}113 \text { anak pra } \\
\text { sekolah, Ithaca, } \\
\text { NY, USA }\end{array}$ & $\begin{array}{l}\text { Recall } 24 \\
\text { jam }\end{array}$ & SFD & $\begin{array}{r}\text { Analisis/ } \\
\text { korelasi } \\
\text { bivariat }\end{array}$ & $\begin{array}{l}\text { Umur } \\
\text { J enis kelamin } \\
\text { Ukuran Rumahtangga } \\
\text { Pendapatan Rumahtangga } \\
\text { Pendidikan Ayah } \\
\text { Pengetahuan Gizi Ibu } \\
\text { Pendidikan Ibu } \\
\text { Status pekerjaan ibu }\end{array}$ & $\begin{array}{l}\text { Ns } \\
\text { Ns } \\
\text { Ns } \\
\text { Ns } \\
\text { Ns } \\
\text { S }(0.28) \\
\text { Ns } \\
\text { Ns } \\
\end{array}$ \\
\hline 3 & $\begin{array}{l}\text { Lee } \\
(1991)\end{array}$ & $\begin{array}{l}15000 \\
\text { Rumahtangga } \\
\text { (NFCS), USA }\end{array}$ & $\begin{array}{l}\text { Record } \\
\text { konsumsi } 7 \\
\text { hari }\end{array}$ & SFD & $\begin{array}{l}\text { Multiple } \\
\text { regresi }\end{array}$ & $\begin{array}{l}\text { Ukuran Rumahtangga } \\
\text { Komposisi Rumahtangga } \\
\text { Biaya Pangan } \\
\text { Pendidikan Ibu } \\
\text { Status Pekerjaan Ibu } \\
\text { Musim (4 musim) } \\
\text { Wilayah } 1 \text { (desa-kota) } \\
\text { Wilayah } 2 \text { (utara-selatan) }\end{array}$ & \begin{tabular}{|l}
$S$ \\
$S$ \\
$S$ \\
$S$ \\
$S$ \\
Ns \\
Ns \\
S \\
\end{tabular} \\
\hline 4 & $\begin{array}{l}\text { Lee et al. } \\
\text { (1989) }\end{array}$ & $\begin{array}{l}1061 \text { Rumahtangga, } \\
\text { wilayah timur laut, } \\
\text { USA } \\
\end{array}$ & $\begin{array}{c}\text { Rocord } \\
\text { konsumsi } \\
14 \text { hari }\end{array}$ & $\begin{array}{l}\text { WFD: Indeks Shannon, } \\
\text { Indeks Harfindahl, } 19 \\
\text { kelompok pangan }\end{array}$ & $\begin{array}{l}\text { Multiple } \\
\text { regresi }\end{array}$ & $\begin{array}{l}\text { Ukuran Rumahtangga } \\
\text { Komposisi Rumahtangga } \\
\text { Biaya Pangan }\end{array}$ & $\begin{array}{l}\mathrm{S} \\
\mathrm{S} \\
\mathrm{S}\end{array}$ \\
\hline 5 & $\begin{array}{l}\text { Dewey } \\
(1981)\end{array}$ & $\begin{array}{l}76 \text { anak pra } \\
\text { sekolah, Socios, } \\
\text { Meksiko }\end{array}$ & $\begin{array}{l}\text { Recall } 2 \\
\text { hari }\end{array}$ & $\begin{array}{l}\text { WFD: Indeks Dewey, } \\
43 \text { kelompok pangan }\end{array}$ & $\begin{array}{l}\text { Analsis/ } \\
\text { korelasi } \\
\text { bivariat }\end{array}$ & Keragaman Panen & $S(0.25)$ \\
\hline 6 & \begin{tabular}{|l|} 
Kant \\
et al. \\
(1991) \\
\end{tabular} & \begin{tabular}{|l|}
11529 orang \\
dewasa (NHANES \\
II), USA \\
\end{tabular} & $\begin{array}{l}\text { Recall } 24 \\
\text { jam }\end{array}$ & $\begin{array}{l}\text { WFD: Score } 1 \text { Kant, } 5 \\
\text { kelompok pangan }\end{array}$ & $\begin{array}{l}\text { Multiple } \\
\text { regresi }\end{array}$ & $\begin{array}{l}\text { Pendidikan } \\
\text { Rasio indeks kemiskinan }\end{array}$ & $\begin{array}{l}S \\
S\end{array}$ \\
\hline 7 & $\begin{array}{l}\text { Hardinsyah } \\
\text { (1996) }\end{array}$ & $\begin{array}{l}17117 \text { rumahtangga } \\
\text { (Susenas), } \\
\text { Indonesia }\end{array}$ & $\begin{array}{l}\text { Recall } 7 \\
\text { hari dgn } \\
\text { food list }\end{array}$ & WFD & $\begin{array}{c}\text { Regresi } \\
\text { berganda }\end{array}$ & $\begin{array}{l}\text { Pendapatan } \\
\text { Harga beras } \\
\text { Paparan media massa } \\
\text { Umur ibu } \\
\text { Pendidikan ibu } \\
\text { Pendidikan ayah } \\
\text { Besar rumahtangga } \\
\text { Daerah pantai } \\
\text { Daerah kota }\end{array}$ & \\
\hline
\end{tabular}

a) Merupakan rasio pendapatan rumahtangga dengan pendapatan yang diperlukan untuk kecukupan konsumsi pangan keluarga. Rasio pendapatan kemiskinan mencerminkan kemampuan ekonomi rumahtangga tersebut.

b) $\mathrm{S}=$ Signifikan $(\mathrm{p}>0.01)$ dan $\mathrm{Ns}=$ tidak siginifikan. Nilai dalam kurung merupakan koefesien korelasi, tetapi tidak semua penelitian menggunakan nilai tersebut.

Pada keluarga yang memiliki cukup akses secara ekonomi dan pemenuhan kebutuhan pangan, pengetahuan gizi orang tua yang baik akan berpengaruh terhadap semakin baiknya keragaman konsumsi pangan anggota keluarganya, yang merupakan cerminan dari perilaku gizi yang baik.

Secara umum, di negara berkembang, ibu memainkan peranan penting dalam memilih dan mempersiapkan pangan untuk dikonsumsi anggota keluarganya. Walaupun seringkali para ibu bekerja di luar, mereka tetap mempunyai andil besar dalam kegiatan pemilihan dan penyiapan makanan (Huffman, 1987; Iwao, 1993). Cohen (1981) mengidentifikasi pola pengambilan keputusan dalam keluarga.
Pola yang umum dalam pengambilan keputusan pemilihan pangan di Indonesia adalah pola istri dominan (keputusan dibuat oleh istri) dan pola sinkretik (keputusan dibuat bersama oleh suami dan istri) (Sayogyo, 1989; Sayogyo, 1990). Pada pola yang pertama sepintas tampak suami mempunyai peran yang kecil dalam menentukan pilihan keragaman jenis pangan. Pada kenyataannya pilihan jenis-jenis makanan yang dibeli atau disiapkan oleh isteri bagi suami dan anggota keluarganya setiap hari merupakan proses pengalaman panjang ibu dalam memahami keinginan suami dan anggota keluarga lainya, sehingga istri memperoleh pengakuan atau kepercayaan untuk melakukan pilihan pangan yang disukai anggota keluarganya. 
Saat kedua orang tua memegang peranan penting dalam pemilihan pangan untuk anggota keluarganya, maka pengetahuan gizi keduanya akan mempengaruhi jenis pangan dan dan mutu gizi makanan yang dikonsumsi anggota keluarga.

Oleh karena itu, tingkat pengetahuan gizi yang baik dapat mewujukan perilaku atau kebiasaan makan yang baik pula. Meskipun pada kenyataannya hubungan antara pengetahuan gizi dan kebiasaan makan tidak sederhana (Den Hartog, 1983; Sayogyo, 1990). Goldfarb (1985), J ohnson (1985) serta KapkaSchutt dan Mitchell (1992) mengungkap bahwa tingkat pengetahuan gizi yang baik secara konsisten terwujud menjadi perilaku makan yang baik. Tetapi beberapa peneliti berpendapat bahwa tingkat pengetahuan gizi yang baik tidak selalu terwujud dalam perilaku makan yang baik karena adanya faktor daya beli pangan yang rendah dan keterbatasan waktu untuk mengolah makanan atau mempersiapkan makanan. Masyarakat miskin bisa jadi tidak dapat mengonsumsi aneka ragam pangan yang baik meskipun mereka berada dekat dari pasar yang menjual aneka ragam pangan dan memiliki pengetahuan gizi yang baik (Lang, 1992; Schafer et al., 1993; PerAndersen, 1987; Food and Agricultura Organization, 1987).

Penelitian yang dilakukan oleh Schafer et al. (1993) mengungkap bahwa alasan ekonomi merupakan pertimbangan pertama dalam pemilihan pangan pada warga Amerika sedangkan yang menjadi pertimbangan kedua adalah kandungan gizi dari bahan pangan tersebut dimana hal itu mencerminkan variabel pengetahuan gizi. Di Afrika, peningkatan alokasi waktu wanita pada kegiatan-kegiatan ekonomi telah mengurangi frekuensi mereka dalam memasak dan semakin berkurangnya jenis bahan pangan yang dimasak walaupun mereka telah dilibatkan dalam program pendidikan gizi (Food and Agriculture Organization, 1987). Keluarga dengan ibu yang bekerja di bidang profesional lebih memilih untuk mengonsumsi buah dan makanan yang telah siap santap dibandingkan dengan keluarga dengan ibu tidak bekerja. Hal ini terjadi karena makin terbatasnya waktu yang tersedia untuk penyiapan makanan (Gofton \& Ness, 1991) sehingga cukup beralasan jika pengetahuan gizi, pendapatan dan alokasi waktu ibu berpengaruh terhadap keragaman konsumsi pangan.

Preferensi atau kesukaan dan kepercayaan seseorang terhadap jenis pangan terten- tu dapat meniadakan pengaruh baik pengetahuan gizi dalam perilaku mengonsumsi anekaragam pangan bergizi. Kesukaan terhadap jenis pangan tertentu baik yang rasional maupun irrasional, dapat ditemukan pada beberapa kelompok agama, etnis atau fisiologis tertentu (Williams, 1992; Renner, 1944; Herman, 1990; Eschleman, 1991). Pangan yang tidak haIal, meskipun bergizi tidak dimakan kelompok agama Islam (Eschleman, 1991). Reaburn et al. (1974) melaporkan bahwa para wanita di wilayah selatan Ontario menghindari untuk mengkonsumsi hati sapi (bahan pangan sumber protein dan zat besi) karena alasan tidak suka. Susu sapi tidak dianggap sebagai bagian yang penting dalam susunan menu makanan di China sehingga etnis China kurang suka minum susu (Eschleman, 1991). Contoh yang lain adalah wanita hamil yang tidak suka aroma dan rasa bakso padahal ketika tidak hamil sangat menyukai bakso.

Ketersediaan pangan dan kekhawatiran yang berlebihan juga dapat membiaskan pengaruh pengetahuan gizi terhadap perilaku makan (Per-Andersen, 1987; Ellis et al., 1976). Kelangkaan pangan karena bencana alam atau gangguan distribusi pangan bisa jadi membuat orang tidak bisa mengonsumsi pangan bergizi kesukaannya. Kekhawatiran yang berlebihan seperti trauma mengonsumsi saturan hijau yang berulat bisa jadi membuat seseorang tidak berkenan lagi makan sayuran hijau seumur hidup meskipun dia tahu bahwa saturan hijau itu bergizi.

Dari uraian di atas tampak jelas bahwa pengetahuan gizi dapat mempengaruhi keragaman konsumsi pangan penduduk. Meskipun demikian, pengaruh positif pengetahuan gizi terhadap keragaman konsumsi pangan dapat berubah atau ditiadakan oleh faktor daya beli atau ekonomi, ketersediaan waktu untuk membeli atau menyiapkan makanan, kepercayaan, kesukaan pangan dan, ketersediaan pangan.

\section{Pendidikan Formal dan Paparan Media Massa}

Tingkat pendidikan formal umumnya mencerminkan kemampuan seseorang untuk memahami berbagai aspek pengetahuan, termasuk pengetahuan gizi. Di suluruh negara, termasuk Indonesia, pengetahuan gizi secara formal (dari tingkat SD sampai SMU) diajarkan sebagai pendidikan gizi, bagian dari pelajaran Ekonomi Rumahtangga (Syarief et al., 1988). Soper et al. (1992) telah menunjukkan bahwa tingkat pendidikan formal secara positif berasosiasi dengan pengetahuan gizi para instruktur aerobik di Texas. Di Indonesia, pengetahu- 
an gizi juga diajarkan sebagai bagian dari pendidikan nonformal, terutama yang melibatkan wanita dalam organisasi atau kelompok sosial seperti dalam PKK, Pos Pelayanan Terpadu (POSYANDU) dan organisasi Dharma Wanita. Jadi, partisipasi wanita dalam berbagai kegiatan sosial (PKK, POSYANDU, Dharma Wanita) akan dapat mempengaruhi pengetahuan gizi mereka (jadi lebih baik) karena mereka mendapat pendidikan gizi sebagai bagian dari pendidikan nonformal.

Semakin tinggi pendidikan seseorang, maka aksesnya terhadap media massa (koran, majalah, media elektronik) juga makin tinggi yang juga berarti aksesnya terhadap informasi yang berkaian dengan gizi juga semakin tinggi. Wanita terpelajar cenderung untuk tertarik terhadap informasi gizi dan banyak di antara mereka yang memperoleh informasi tersebut dari media cetak, khususnya majalah dan koran (Hickman et al., 1993). Sebuah penelitian yang dilakukan di Indonesia menunjukkan bahwa ibu dengan tingkat pendidikan dan penghasilan lebih tinggi mendapat paparan dari media massa lebih tinggi juga (National Board for Family Planning (BKKBN) and Community System Foundation, 1986). Di Indonesia, seseorang dengan tingkat pendapatan lebih tinggi relatif lebih mudah mengakses TV dan mereka yang tinggal di daerah perkotaan lebih mudah mengakses berbagai majalah populer. Berdasarkan hasil penelitian Jacobs (1981) di USA dinyatakan bahwa artikel gizi dan kesehatan dari majalah-majalah populer jauh lebih akurat dan detil jika dibandingkan dengan artikel serupa yang berasal dari koran. Oleh karena itu, tingkat pendidikan orang tua, pendapatan rumahtangga dan wilayah tempat tinggal (desa atau kota) diasumsikan mempengaruhi kondisi individu seseorang/rumahtangga untuk terpapar media massa. Rozenwig (1986) serta Wolfe dan Behrman (1982) menyatakan bahwa pasangan orang tua dengan usia lebih tinggi kemungkinan mempunyai pengetahuan gizi dan kesehatan lebih baik jika dibandingkan dengan pasangan orang tua dengan usia muda karena pengalaman mereka dalam menggunakan berbagai layanan kesehatan. Tetapi, Wolfe mencatat bahwa pasangan orang tua dengan usia dengan usia lebih tinggi mungkin mempunyai kekurangan informasi tentang pengetahuan gizi yang terbaru jika dibandingkan dengan pasangan orang tua dengan usia muda (Wolfe \& Behrman, 1982). Hal ini terjadi karena perkembangan ilmu gizi dan berbagai promosi produk-produk gizi dan kesehatan. Pengalaman dalam menderita penyakit karena keku- rangan/ kelebihan zat gizi tertentu dapat meningkatkan pengetahuan gizi (Wolfe \& Behrman, 1982; Mann \& Huddleston, 1987). Orang yang menderita penyakit tersebut biasanya mendapat berbagai saran dari ahli gizi dan kesehatan atau bahkan dari temantemannya untuk memasukkan bahan pangan yang mengandung zat gizi tertentu dalam susunan dietnya. Berdasarkan hal tersebut dapat dikatakan bahwa kelompok orang dengan pendapatan yang lebih tinggi kemungkinan memiliki pengalaman di bidang gizi yang lebih baik jika dibandingkan dengan kelompok dengan pendapatan rendah. Selain itu, kelompok orang yang tinggal di daerah perkotaan atau wilayah dengan berbagai fasilitas penunjang lengkap memiliki pengalaman di bidang gizi yang lebih baik dibandingkan kelompok yang tinggal di wilayah pedesaan. Alasannya adalah karena kelompok yang berpendapatan lebih tinggi dan tinggal di daerah perkotaan mempunyai akses ke para ahli gizi dan kesehatan (sebagai sumber informasi gizi) yang lebih mudah.

Pertanyaan yang muncul kemudian adalah apakah pengetahuan gizi yang diperoleh dari berbagai sumber itu relevan/sejalan dengan konsep untuk mengonsumsi beragam jenis makanan untuk meningkatkan kualitas gizi dalam diet. Hubungan antara pengetahuan gizi dan keragaman konsumsi pangan mungkin tidak terlihat jika pengetahuan gizi yang diperoleh tidak relevan/sejalan dengan konsep keragaman konsumsi pangan.

Beberapa penelitian di negara berkembang menunjukkan adanya hubungan yang signifikan antara tingkat pendidikan ibu dengan asupan gizi di tingkat rumahtangga (Kant et al., 1991; Bairagi, 1980; Behrman \& Wolfe, 1987; Behrman et al., 1988). Berdasarkan analisis multivariat (Behrman \& Wolfe, 1987; Behrman et al., 1988), di beberapa negara berkembang, termasuk Indonesia, tingkat pendidikan ibu dipandang sebagai determinan penting dari asupan gizi atau pengelolaan gizi di tingkat rumahtangga. Dengan tingkat pendidikan yang lebih tinggi, para ibu dari rumahtangga berpendapatan rendah dapat lebih mampu untuk mengelola sumberdaya yang dimiliki di rumahtangganya secara lebih efesien dibandingkan para ibu yang berpendidikan rendah (Behrman \& Wolfe, 1987; Behrman et al., 1988; World Bank, 1993). Dengan kata lain, para ibu dengan pendidikan lebih baik dapat memilih dan mengkombinasikan beragam jenis pangan dengan harga yang tidak mahal. 
Belum ada penelitian di negara berkembang yang dilakukan untuk melihat hubungan antara pendidikan (sebagai sumber pengetahuan gizi) dan keragaman konsumsi pangan, maupun hubungan antara setiap faktor determinan yang diduga yang telah disebut di atas (paparan media massa dan pengalaman gizi) dan keragaman konsumsi pangan. Penelitian kecil yang dilakukan oleh Caliendo et al., (1977) di USA dengan menggunakan analisis bivariat gagal menguatkan/menegaskan hubungan antara tingkat pendidikan ibu dengan keragaman konsumsi pangan anak-anak prasekolah (Tabel 1). Hal ini kemungkinan terjadi karena adanya kelemahan pada desain penelitian dan ukuran keragaman konsumsi pangan yang digunakan. Penelitian tersebut dirancang untuk mengidentifikasi prevalensi gizi kurang pada anak-anak prasekolah (pasien sebuah klinik di Ithaca, New York). Anak-anak yang menjadi sampel penelitian tersebut berasal dari pasien klinik dan dipilih dengan metode non-probability sampling. Seluruh ibu dalam penelitian ini umumnya mempunyai tingkat pendidikan yang baik yang ditunjukkan dengan angka variasi yang rendah pada variabel pendidikan. Penelitian tersebut menggunakan skor keragaman konsumsi pangan sederhana dimana skor ini sedikit lebih tepat dibandingkan skor keragaman pangan terbobot, dan dalam analisisnya tidak mempertimbangkan faktor-faktor yang potensial menjadi pengganggu. Selain itu, penelitian tersebut tidak menggunakan data laporan menu diet anak-anak yang sudah ditentukan oleh klinik yang mungkin data keragaman konsumsi pangannya kurang bervariasi (homogen).

Penelitian lain yang dilakukan di wilayah yang sama (sebuah desa kecil di bagian barat New York, USA) oleh (Schorr et al., 1972), menggunakan ukuran keragaman konsumsi pangan yang sama tetapi dengan desain atau rancangan dan metode pengumpulan data pangan yang berbeda (Caliendo et al., 1977), menunjukkan bahwa tingkat pendidikan ibu berkaitan dengan keragaman konsumsi pangan anak-anaknya ( kelompok remaja, pelajar) (Tabel 1). Penelitian Kant et al., (1991) yang menggunakan data survai nasional Amerika (NHANES II) merupakan satu-satunya penelitian yang menganalisis determinan keragaman konsumsi pangan dengan menerapkan skor keragaman pangan terbobot dan pendidikan sebagai sumber pengetahuan gizi. Penelitian tersebut menyatakan bahwa tingkat pendidikan orang dewasa Amerika berhubungan nyata dengan keragaman pangan yang dikonsumsinya. Lima puluh persen orang dewa- sa dalam kelompok dengan tingkat pendidikan tertinggi mempunyai skor keragaman konsumsi pangan tertinggi pula (skor 20), sedangkan skor yang sama hanya diperoleh 27 persen orang dewasa dalam kelompok dengan tingkat pendidikan terendah. Nilai koefesien korelasi penelitian ini tidak dipublikasikan/ disebutkan.

Berdasarkan review di atas, pendidikan gizi, paparan media massa dan pengalaman gizi diduga berpengaruh terhadap pengetahuan gizi yang akhirnya akan mempengaruhi keragaman konsumsi pangan. Selain itu, tingkat pendidikan orang tua (ayah dan ibu), Usia kedua orang tua, partisipasi ibu dalam kegiatan sosial, pendapatan rumahtangga dan lokasi tempat tinggal (desa atau kota) kemungkinan menentukan keragaman konsumsi pangan rumahtangga melalui empat variabel yang disebut pendidikan gizi, paparan media massa, pengalaman gizi dan pengetahuan gizi.

\section{Pengeluaran Pangan dan Harga}

Faktor penting yang diduga sebagai determinan dalam keragaman konsumsi pangan adalah daya beli pangan. Pola 'daya beli pangan' ini merupakan hal yang umum dalam pustaka ekonomi, walaupun hal ini tidak dapat diukur secara langsung. Daya beli pangan biasanya didefinisikan sebagai kemampuan ekonomi rumahtangga untuk memperoleh bahan pangan yang ditentukan oleh besarnya alokasi pendapatan untuk pangan, harga bahan pangan yang dikonsumsi, dan jumlah anggota rumahtangga (Immink, 1982; PinstrupAndersen, 1985; Foster, 1992). Dengan kata lain, daya beli pangan tergantung pada besarnya pendapatan dan harga bahan pangan. Karena daya beli pangan tidak mempunyai ukuran yang jelas, maka pengukuran daya beli pangan dilakukan dengan pendekatan berbagai faktor determinan/penentunya, seperti alokasi pendapatan untuk pangan (selanjutnya disebut biaya pangan), harga pangan dan ukuran rumah tangga. Pandangan umum mengenai hubungan antara biaya pangan dan keragaman konsumsi pangan berasal dari hipotesis yang menyatakan bahwa seiring berubahnya pengeluaran pendapatan untuk pangan, maka rumahtangga akan merubah jumlah dan jenis pangan yang dikonsumsinya sesuai dengan harga pangan yang tersedia. Tetapi besarnya biaya pangan untuk pembelian beragam pangan tidak hanya bergantung pada besarnya pendapatan rumahtangga, tapi juga bergantung pada pengetahuan gizi penentu (kepala rumahtangga/ibu rumahtangga) pembelian pangan dan komposisi anggota rumahtangga. 
Dua penelitian di USA yang menggunakan data nasional (penelitian pertama (Lee \& Brown, 1989) menggunakan data Survei Belanja Konsumen Nasional/ NCES dan penelitian kedua (Lee, 1987) menggunakan data Survei Konsumsi Pangan Nasional/NFCS) menyimpulkan bahwa semakin tinggi biaya pangan suatu rumahtangga maka akan semakin beragam konsumsi pangan rumahtangga tersebut (Tabel 1). Untuk mengetahui dampak turunan biaya pangan pada keragaman konsumsi pangan, penelitian kedua menerapkan logaritma biaya pangan dalam analisis modelnya. Walaupun penelitian pertama menggunakan indeks Shannon dan Herfindahl sebagai ukuran keragaman konsumsi pangan dan penelitian kedua menggunakan SFD, mengingat akan kurang tepat jika menggunakan WFD, kedua penelitian tersebut menunjukkan bahwa dengan penggunaan analisis multivariat, ukuran rumahtangga, komposisi rumahtangga dan biaya pangan akan berpengaruh signifikan terhadap keragaman konsumsi pangan.

Teori mikroekonomi menyebutkan bahwa harga pada beberapa komoditi/ barang tertentu berpotensi untuk mempengaruhi jumlah dan/atau jenis komoditi/barang yang dibeli (Pinstrup-Andersen, 1985; Foster, 1992; Raunikar \& Huang, 1987; Tyrell \& Mount, 1987). Berdasarkan teori umumnya, hubungan antara harga pangan dan keragaman konsumsi pangan dapat dijelaskan. Analisis pada data SUSENAS tahun 1987 menunjukkan bahwa harga beras merupakan faktor yang secara signifikan menentukan asupan kalori/energi pada rumahtangga di Indonesia (Ravallion, 1992). Dengan menggunakan data SUSENAS tahun 1978, Pitt dan Rosenzwig (1985) menganalisis hubungan antara agregat/total harga kelompok pangan dan asupan gizi. Hasil dari penelitian itu menunjukkan bahwa peningkatan harga pangan akan mengakibatkan penurunan sebagian besar asupan zat gizi dari pangan. Contohnya jika harga daging, susu dan ikan meningkat, maka asupan protein akan menurun; begitu juga dengan konsumsi vitamin $A$ dan C jika harga sayuran dan buah-buahan meningkat. Hasil yang sama ditunjukkan pada penelitian Bouis (210) yang menggunakan data rumahtangga petani Filipina. Hasil-hasil tersebut mengimplikasikan bahwa setidaknya untuk beberapa komoditi pangan jika mengalami perubahan harga maka jumlah dan jenis pangan yang dikonsumsi juga akan berubah.

Teori harga menyatakan bahwa harga pangan di daerah tertentu dipengaruhi oleh ketersediaan dan permintaan komoditi pangan tersebut (Pinstrup-Andersen, 1985; Bouis,
1989). Perbedaan kualitas di antara bahan pangan yang serupa, seperti perbedaan rasa dan karaktristik gizi serta pengemasan akan dapat mengakibatkan perbedaan harga (Immink, 1982; Giese, 1994; Lyman, 1989). Dengan menggunakan data suatu penelitian crossectional di USA (NFCS), Lee (1987) menggunakan variabel wilayah sebagai variabel dummy untuk mengetahui perbedaan harga secara sistematis antara wilayah karena data harga pangan tidak dikumpulkan. Berdasarkan data NFCS, Bikeway (Buce, 1987) mencatat bahwa data crossectional (NFCS) menunjukkan variasi harga yang rendah yang berarti variabel harga pangan tersebut tidak dapat mendukung hasil penelitiannya. Tetapi seperti telah dibahas pada bagian sebelumnya, Pitt dan Rosenzweig (1985) serta Ravallion (1992) menggunakan data crossectional yang berasal dari Indonesia (SUSENAS) untuk menganalisis hubungan antara agregat/total harga kelompok pangan dan asupan gizi. Hasil dari penelitian-penelitian tersebut menyatakan bahwa harga pangan dapat dianggap sebagai salah satu determinan dalam konsumsi pangan di Indonesia. Oleh karena itu, biaya pangan dan harga pangan adalah dua faktor penting, sebagai komponen daya beli pangan, yang diduga menjadi determinan keragaman konsumsi pangan di Indonesia.

Berkenaan dengan metode analisis harga pangan, karena konsumsi meliputi beragam pangan, maka harga-harga satuan pangan jadi mungkin untuk dianalisis (Pitt \& Rosenzweig, 1985; Pinstrup-Andersen et al., 1976; Timmer \& Alderman, 1979; Goungetas et al., 1993). J adi hal itu lebih tepat menggunakan harga agregat kelompok pangan atau harga pangan tertentu yang superior atau dalam hal ini dikenal luas dan bergizi tinggi, seperti yang dianjurkan oleh para peneliti (Pitt \& Rosenzweig, 1985; Pinstrup-Andersen et al., 1976; Timmer \& Alderman, 1979; Goungetas, 1993).

\section{Pendapatan}

Pendapatan merupakan determinan yang dikenal luas dalam model perilaku konsumen, dan juga termasuk dalam model penawaran pangan. Rumahtangga sebagai satuan/ unit primer penghasil pendapatan juga merupakan unit primer konsumsi pangan. Semakin tinggi pendapatan rumahtangga maka akan semakin tinggi pula pendapatan yang dialokasikan untuk pangan (biaya pangan) (Raunikar \& Huang, 1987; Goungetas et al., 1993; PinstrupAndersen \& Caicedo, 1978). Seperti telah dibahas dalam bagian 2.6.3 bahwa semakin tinggi alokasi pendapatan untuk pangan maka akan semain tinggi daya beli pangan yang pada ak- 
hirnya akan meningkatkan keragaman konsumsi pangan (Lee \& Brown, 1989). Pandangan umum mengenai hubungan antara pendapatan dan keragaman konsumsi pangan berasal dari bukti empiris umum bahwa ada perbedaan pola konsumsi pangan pada kelompok masyarakat menengah ke atas dan menengah ke bawah. Umumnya pola konsumsi pangan kelompok menengah ke bawah lebih sederhana dimana mereka lebih mengutamakan mengonsumsi sumber kalori yang murah (bahan pangan pokok), sedangkan pada kelompok menengah ke atas pola konsumsi pangannnya lebih beragam dengan lebih banyak mengonsumsi pangan sumber protein dan vitamin (Kantor Menteri Koordinator Kesejahteraan Rakyat, 1989; Raunikar \& Huang, 1987; Shah, 1983; Bouis, 1990).

Ada dua penelitian yang menganalisis hubungan antara pendapatan rumahtangga dengan keragaman konsumsi pangan (Caliendo et al., 1977; Kant et al., 1991). Kedua penelitian tersebut dilakukan di negara maju USA. Penelitian pertama dilakukan oleh Caliendo et al. (1977) pada 113 anak prasekolah yang hasilnya menunjukkan bahwa tidak ada hubungan yang signifikan antara pendapatan rumahtangga dengan keragaman konsumsi pangan anak-anak prasekolah. Penelitian kedua (Kant et al., 1991) menggunakan sampel dalam jumlah besar (11 967 orang dewasa dari data NHANES II) menunjukkan bahwa semakin tinggi pendapatan maka semakin beragam konsumsi pangannya (Tabel 1). Penjelasan yang mungkin untuk penelitian yang pertama sama dengan penjalasan yang dibahas dalam bagian 2.6.2, yaitu karena adanya kelemahan desain penelitian dan ukuran keragaman konsumsi pangan.

Ravallion (1992), dengan menggunakan data SUSENAS tahun 1987, menunjukkan bahwa pendapatan rumahtangga berhubungan dengan asupan total kalori dan asupan kalori dari kelompok pangan utama. Semakin tinggi pendapatan rumahtangga maka semakin tinggi asupan kalori dari kelompok pangan hewani, sayur dan buah-buahan. Hal tersebut mengimplikasikan bahwa semakin tinggi pendapatan maka semakin tinggi kemungkinan untuk mengonsumsi beragam jenis pangan.

Pengumpulan data pendapatan rumahtangga di negara berkembang seperti di Indonesia masih tetap mengalami kesulitan. Besarnya pendapatan yang dilaporkan oleh rumahtangga berpendapatan tinggi cenderung lebih rendah dari yang sebenarnya karena mereka ingin mengurangi atau menghindari pajak dan pada rumahtangga yang berpendapatan rendah, hal yang sama juga terjadi karena mereka cenderung mengabaikan hutang-hutang serta pendapatan lain yang sejenis (Sigit, 1985; van de Walle, 1988). Para ahli ekonomi berpendapat bahwa di negara berkembang, meskipun arus pendapatan dapat diukur dengan tepat, pengeluaran total kemungkinan tetap lebih tepat sebagai determinan konsumsi karena pengeluaran total lebih mewakili besarnya pendapatan tetap atau yang biasa disebut sebagai pendapatan dan aset rumahtangga (Immink, 1982; van de Walle, 1988; Atkinson 1975). Perubahan sesaat pada pendapatan rumahtangga akan berpengaruh kecil terhadap pengeluaran rumahtangga. Oleh karena itu, pengeluaran rumahtangga yang mewakili pendapatan tetap lebih tepat digunakan untuk analisis konsumsi pangan, khususnya di Indonesia (Megawangi, 1991; Sigit, 1985; van de Walle, 1988).

\section{Status dan Jenis Pekerjaan Ibu}

Faktor ketiga yang diduga sebagai determinan keragaman konsumsi pangan (dibahas dalam bagian 2.6.1) adalah waktu ibu yang tersedia untuk penyiapan pangan (selanjutnya disini disebut waktu yang tersedia). Keterlibatan ibu dalam kegiatan ekonomi dibatasi oleh waktu mereka untuk kegiatan domestik/ rumahtangga, termasuk pengelolaan pangan di rumahtangga (Huffman 1987). Horton dan Campbell (1991) menyatakan bahwa jika ibu bekerja di luar rumah, maka akan ada dua dampak terhadap pola konsumsi rumahtangganya. Dampak yang pertama yaitu adanya peningkatan terhadap pangan yang dikonsumsi rumahtangga. Kualitas pangan yang dikonsumsi akan tetap normal atau bahkan jadi lebih baik. Dampak yang kedua yaitu terjadinya perubahan dalam waktu untuk kegiatan konsumsi dan kegiatan rumahtangga lainnya yang menjadi lebih singkat. Berdasarkan pola pikir tersebut, maka faktor-faktor yang diduga berpengaruh terhadap ketersediaan waktu ibu adalah status dan jenis pekerjaan ibu, kehadiran ibu di rumah, ketersediaan berbagai peralatan masak modern dan ketersediaan pangan yang praktis (siap saji/ siap santap).

Saat ini, jumlah wanita (ibu) yang terlibat dalam sektor formal jadi semakin banyak, khususnya di daerah perkotaan dan jumlah tersebut akan terus meningkat sebagai konsekuensi dari perkembangan sosial ekonomi. Alasan para wanita tersebut bekerja umumnya merupakan alasan ekonomi yaitu untuk memperbaiki kondisi ekonomi rumahtangganya (Huffman, 1987; McGuire \& Popkin, 1989; Chatterjee, 1989; Zeitlin et al., 1992; 
Iwao, 1993). Beberapa dari mereka, khususnya yang terpelajar dan berasal dari rumahtangga berpendapatan tinggi masuk ke dunia kerja bukan hanya karena alasan ekonomi. Alasan mereka bekerja adalah agar mereka dapat mengaktualisasikan dirinya, meningkatkan pengetahuan dan wawasan yang mereka miliki serta berasosiasi dengan orang lain (Adrian \& Daniel, 1976). Keterlibatan para ibu tersebut akan berpengaruh terhadap keragaman konsumsi pangan dan asupan gizi rumahtangganya karena mereka berperan penting dalam kegiatan pengelolaan pangan untuk anggota rumahtangganya (Huffman, 1987; Campbell \& Sanjur, 1992; Kirk \& Gillespie, 1990). Besarnya pengaruh dari berbagai faktor yang disebutkan sebelumnya juga bergantung pada jenis pekerjaan yang dilakukan ibu (di dalam atau di luar rumah). Faktor-faktor yang mempengaruhi hal itu adalah kehadiran pembantu di rumah, waktu yang tersedia untuk pengelolaan peralatan memasak dan waktu yang tersedia untuk pengelolaan pangan.

Rumahtangga di Kanada dengan ibu yang bekerja penuh di luar rumah mengonsumsi lemak, karbohidrat dan kalori lebih sedikit tetapi mengonsumsi vitamin A dan C lebih banyak dibandingkan dengan ibu yang bekerja di rumah (Horton \& Campbell, 1991). Rumahtangga di Amerika yang mempunyai pendapatan lebih tinggi mempunyai elastisitas konsumsi vitamin C yang lebih tinggi pula (Adrian \& Daniel, 1976). Sebanyak 70 persen vitamin C dalam menu makanan masyarakat Amerike berasal dari buah-buahan dan salad (Robinson, 1968). Hal tersebut menunjukkan bahwa ibu yang bekerja di luar rumah mengurangi konsumsi pangan sumber kalori dan lemak dan meningkatkan konsumsi sayur dan buah pada rumahtangganya yang berarti konsumsi pangan rumahtangganya jadi lebih beragam.

Sebuah penelitian di Skotlandia memperkuat hasil penelitian di atas. Rumahtangga dengan ibu bekerja di luar rumah lebih banyak mengonsumsi buah daripada rumahtangga dengan ibu di rumah. Hal itu dilakukan karena alasan waktu untuk pengelolaan pangan yang lebih singkat (Gofton \& Ness, 1991). Hal ini juga didukung dengan hasil Survei Gizi Victoria yang menyebutkan bahwa ibu yang bekerja di luar rumah lebih banyak mengonsumsi beragam sayur dan buah (Worsley 1991). Penjelasan yang masuk akal untuk rendahnya konsumsi kalori, karbohidrat dan lemak pada ibu-ibu yang bekerja di luar rumah adalah karena mereka lebih peduli dengan berat badannya daripada ibu-ibu yang di rumah. Seperti yang dicatat Abraham (1988) bahwa pandangan ten- tang body image, tubuh yang langsing, dan penampilan yang menarik merupakan hal yang penting bagi wanita Australia untuk mendapat pekerjaan yang baik, sukses dalam karier dan pergaulan. Walaupun mereka banyak meng- konsumsi makanan yang diolah di rumahtang- ga, mereka lebih memilih jenis makanan yang rendah lemak, salad dan buahbuahan.

Seperti yang telah dibahas sebelumnya, Becker (1965) menyatakan rumahtangga dengan ibu yang bekerja mungkin lebih banyak mengonsumsi makanan yang praktis (siap santap/siap saji) daripada rumahtangga dengan ibu yang tinggal di rumah. Hal-hal berikut merupakan bagian dari pengelolaan pangan yang praktis di rumahtangga. Pertama, berbagai kompor gas atau listrik, oven, mikrowave, lemari es dan lainnya yang tergolong sebagai peralatan masak modern. Kedua adalah makanan siap santap, siap saji dan golongan bahan pangan yang dapat langsung dikonsumsi seperti sayur dan buah. Ketersediaan peralatan masak modern di rumahtangga serta kemudahan akses terhadap berbagai pangan yang praktis dapat mengurangi atau bahkan menghilangkan peranan ibu dalam pengelolaan pangan di rumahtangga (Wahlqvist, 1988; Miller, 1990; Burnett \& Rees, 191).

Contoh lain sebagai dampak dari makin berkembangnya penggunaan pangan yang praktis adalah di J epang dimana rata-rata waktu yang dialokasikan oleh wanita untuk kegiatan domestik termasuk pengelolaan pangan di rumahtangga, selama tiga dekade ini mengalami penurunan sampai $20 \%$ yaitu dari 51.8 jam menjadi $41.8 \mathrm{jam}$ per minggu. Selama periode tersebut konsumsi pangan yang dikelola di rumahtangga juga mengalami peningkatan (Iwao, 1993). Hal ini merupakan penjelasan mengapa di negara maju, rumahtangga dengan ibu yang bekerja dapat mengonsumsi beragam jenis pangan.

Di Indonesia, beragam jenis pangan yang dikelola rumahtangga tersedia baik di daerah perkotaan maupun di pedesaan. Harga dari pangan tersebut berbeda antara di wilayh perkotaan dengan di pedesaan. Sesuai dengan data CBS (1992), pada tahun 1990 rata-rata pengeluaran rumahtangga untuk pangan adalah sebesar $8.4 \%$ Seorang pembantu atau wanita anggota rumahtangga yang tinggal di rumah biasanya menggantikan peran ibu untuk mengelola pangan di rumahtangga. Di daerah perkotaan, sekalipun ibu rumahtangga tidak bekerja di luar rumah biasanya tetap memiliki pembantu karena keinginan anggota rumah- 
tangga, termasuk ibu untuk memiliki waktu luang yang lebih banyak. Rumahtangga dengan pendapatan tinggi, khususnya yang tinggal di daerah perkotaan biasanya mempunyai peralatan masak modern juga.

Beberapa penelitian telah dilakukan untuk mengetahui efek dari status dan jenis pekerjaan ibu terhadap asupan gizi dan makanan rumahtangga di negara berkembang. Huffman (1987) mencatat bahwa permintaan yang tinggi terhadap alokasi waktu wanita untuk kegiatan ekonomi dan kegiatan rumahtangga pada rumahtangga menengah ke bawah dapat mempengaruhi variasi pangan yang dikonsumsi. Seperti yang telah dibahas di bagian 2.6.1, di negara berkembang, wanita memegang peranan penting dalam pengelolan pangan rumahtangga. Saat wanita dari rumahtangga menengah ke bawah lebih banyak mengalokasikan waktunya untuk kegiatan ekonomi/bekerja di luar rumah, biasanya mereka akan mengurangi waktu untuk mengelola makanan di rumahtangga dengan cara mengurangi frekeunsi memasak atau mengurangi jenis makanan yang dimasak yang pada akhirnya akan mengurangi kualitas gizi pada menu makanannya (Food and Agriculture Organization, 1987). Pada kasus ini, keberadaan saudara atau anggota rumahtangga wanita yang berusia remaja (Adrian \& Daniel, 1976; Choudry et al., 1986; Leibowitz, 1974; Popkin, 1980) akan dapat mencegah terjadinya dampak buruk yang disebutkan sebelumnya.

Walaupun demikian, tidak ada penelitian di negara berkembang yang menganalisis hubungan antara status dan jenis pekerjaan ibu dengan keragaman konsumsi pangan rumahtangganya. Seluruh penelitian yang telah disebutkan sebelumnya dilakukan di negara maju (ditunjukkan di Tabel 1). Penelitian yang dilakukan Caliendo et al., (1977) menunjukkan bahwa tidak ada hubungan yang signifikan antara status dan jenis pekerjaan ibu dengan keragaman konsumsi pangan anakanaknya. Kelemahan dari penelitian ini telah disebutkan di bagian 2.6.2. Penjelasan Iain untuk hasil penelitian ini yaitu kemungkinan rumahtangga dengan ibu bekerja di luar rumah memiliki pembantu atau menggunakan berbagai peralatan masak modern dan anakanaknya makan siang di tempat penitipan anak. Hal yang disayangkan dari penelitian ini adalah tidak disebutkannya berbagai faktor yang mungkin menjadi faktor pengganggu/ confounder.

Penelitian yang dilakukan oleh Schorr et al. (1972) di sebuah desa kecil di USA menun- jukkan bahwa ada hubungan yang positif dan signifikan antara status dan jenis pekerjaan ibu dengan keragaman konsumsi pangan anakanaknya. Penelitian lain yang dilakukan oleh Lee (1987), menggunakan analisis multivariat dan jumlah sampel yang besar menyimpulkan bahwa status dan jenis pekerjaan ibu merupakan determinan keragaman konsumsi pangan rumahtangga. Jenis pangan yang dikonsumsi pada rumahtangga dengan ibu yang bekerja di luar lebih sedikit dibandingkan dengan rumah tangga tanpa wanita/ibu yang bekerja di luar rumah. Penjelasan untuk hal ini adalah karena adanya perbedaan karakteristik populasi pada kedua penelitian tersebut (dalam hal pendapatan, pendidikan dan kebudayaan) dan perbedaan metode analisis yang digunakan.

Oleh karena itu, status dan jenis pekerjaan ibu, kehadiran pembantu dalam rumahtangga, ketersediaan berbagai peralatan masak modern dan bahan-bahan pangan praktis, yang seluruhnya mempengaruhi ketersediaan waktu ibu untuk mengelola pangan cenderung untuk menjadi determinan keragaman konsumsi pangan di rumahtangga. Tetapi belum ada penelitian yang secara sistematis menganalisis dampak dari berbagai faktor yang diduga sebagai determinan tersebut yang dilakukan di Indonesia, dimana jumlah wanita yang terlibat di pasar tenaga kerja semakin meningkat.

\section{Preferensi dan Ketersediaan Pangan}

Preferensi/kesukaan pangan biasanya merujuk pada daya terima dari pangan tersebut, yang dipengaruhi oleh kebiasaan, kualitas rasa pangan dan zat gizi yang terkandung dalam pangan tersebut (Giese, 1994; Lyman, 1989; Wahlqvist, 1988). Preferensi pangan ada yang bersifat tetap sepanjang waktu dan da juga yang dapt berubah dari waktu ke waktu. Seringkali sesorang atau kelompok etnis tertentu tidak menyukai pangan-pangan tertentu (Lyman 1989). Selain itu preferensi pangan juga dapat berbeda di antara kelompok umur dan jenis kelamin (Lyman, 1989; Buce, 1987), seperti pada anak-anak dan orang dewasa.

Setiap kelompok sosial memiliki tradisi dan kepercayaan tertentu yang berhubungan dengan pangan, apakah bersifat rasional atau irasional, menguntungkan atau merugikan, yang pada mulanya berkembang karena ketersediaan pangan di tempat tersebut dan juga berhubungan dengan nilai-nilai budaya dan agama kelompok etnik tersebut (Eschleman, 1991; Wahlqvist, 1988; Ramington, 1948). Me- 
nurut Ramington (1948), kebiasaan makan pada satu atau kelompok orang terbentuk karena faktor ekologi dimana kelompok tersebut tinggal. Tanah dan iklim menentukan produksi dan ketersediaan pangan. Lebih Ianjut, faktor tradisi dan kepercayaan mengatur penerimaan pangan, pengelolaannya serta preferensi pangan. Preferensi pangan selanjutnya diturunkan dari generasi ke generasi lewat pengalaman dalam keluarga dan hal itu dapat dipengaruhi oleh faktor sosial ekonomi dari waktu ke waktu (Williams, 1992; Wahlqvist, 1988; Ramington, 1948). Secara umum, menu makanan barat biasanya terdiri atas susu, daging, roti dan sereal, buah dan sayur. Seluruh susunan menu makanan orang Asia biasanya terdiri atas nasi, ikan, seafood dan kacang-kacangan serta sayur dan buah. Susu hanya digunakan dalam jumlah terbatas karena kemungkinan adanya prevalensi laktos intolerans dan kurangnya ketersediaan susu (Eschleman, 1991).

Seluruh agama yang ada di dunia secara implisit menganjurkan pemeluknya untuk mengonsumsi beragam jenis makanan. Dalam seluruh agama ada larangan bagi pemeluknya untuk mengonsumsi makanan terten- tu yang jumlahnya sangat terbatas. Makanan yang dilarang tersebut digantikan dengan ma- kanan lain yang secara kandungan gizi hampir sama. Walaupun daging babi dilarang bagi orang Yahudi dan Islam, daging, buah sayuran dan susu mempunyai nilai yang khusus dalam ajaran agama Yahudi, Kristen dan Islam (Williams, 1992; Rahman, 1980).

Saat preferensi pangan diturunkan dari generasi ke generasi, sebagian dari preferensi itu kemungkinan ada yang mengalami perubahan, maka ibu sebagai orang yang berperan penting dalam pengelolaan pangan di rumahtangga akan berperan untuk menerapkan preferensi yang baru tersebut dalam rumahtangganya (Williams, 1992; Wahlqvist, 1988). Preferensi pangan yang baru tersebut biasanya dipengaruhi oleh pengetahuan gizi yang mereka miliki, yang dapat diperoleh dari satu atau lebih informasi gizi dari sumber-sumber yang telah dibahas di bagian 2.6.1, yaitu pengalaman, pendidikan gizi, paparan media massa dan iklan. Randall mencatat bahwa pada keluarga dengan menu makanan yang beragam biasa jadi ada beberapa pangan yang dilarang sebagai bentuk dari preferensi pangan (Randall, 1982).

Pada pertanian subsisten, ketersediaan pangan lokal hanya dipengaruhi oleh produksi pangan lokal dan pangan yang diperoleh dari kegiatan berburu meramu (mengumpulkan ma- kanan). Para petani memproduksi beragam pangan lokal yang sesuai dengan kondisi alam dan berbagai faktor ekologi seperti tanah, iklim, musim dan sumberdaya biologis (Fleuret $P$ \& Fleuret A, 1980; Cooper, 1992). Konsekuensi dari hal tersebut adalah adanya keragaman produksi pangan (pola panen) dan ketersediaan pangan pada pertanian subsisten yang bergantung pada berbagai faktor ekologi. Adanya pengenalan teknologi pertanian baru, peningkatan infrastruktur dan pengelolaan faktor-faktor ekologi telah meningkatkan produksi pangan (Wolfe \& Behrman, 1982). Sejalan dengan hal tersebut, kondisi infrastruktur yang lebih baik, dan teknologi penanganan, pengemasan, penyimpanan serta pengembangan produk pangan yang lebih baik telah meningkatkan distribusi dan akses pangan ke berbagai daerah (Wahlqvist, 1988). Hasil dari hal tersebut yaitu adanya keseragaman jenis kelompok pangan yang tersedia pada daerahdaerah yang berdekatan.

Dewey (Lee \& Brown, 1989) merupakan satu-satunya peneliti yang telah menganalisis hubungan antara keragaman pola panen pangan rumahtangga dengan keragaman konsumsi pangan. Kelemahan penelitian ini yaitu pada ukuran keragaman konsumsi pangan dan hasil penelitian menunjukkan bahwa ada hubungan yang signifikan antara keragaman konsumsi pangan dengan keragaman panen di Socios, Meksiko (Tabel 1). Kedua hal tersebut (keragaman konsumsi pangan dan keragaman panen) tidak mempunyai hubungan yang kuat. Kemungkinan, analisis tersebut dapat lebih tepat di daerah pertanian subsisten atau daerah yang pertaniannya hampir subsisten. Tetapi di daerah pertanian non-subsisten, jenis pangan yang diproduksi mungkin tidak berhubungan dengan jenis produksi pangan lokal.

Di negara maju, keberhasilan produksi pangan, distribusi dan teknologi pangan meningkat, seiring produksi pangan komersial kebutuhan rumahtangga yang ada di pasar yang seluruhnya tidak dipengaruhi oleh musim (Wahlqvist, 1988). Penelitian yang dilakukan oleh Lee (1987) di Amerika menegaskan bahwa tidak ada dampak yang signifikan dari musim (guugur, dingin, semi dan panas) terhadap keragaman konsumsi pangan pada rumahtangga Amerika (Tabel 1). Dalam pertanian nonsubsisten di negara berkembang, walaupun pangan lokal tetap dikonsumsi, jenis konsumsi pangan tidak lagi sama dengan jenis produksi pangan lokal (Dewey, 1980; Harvey \& Heywood, 1983; Leonard \& Thomas, 1988). 
Faktor ekologi/alam dapat berpengaruh juga terhadap kebiasaan yang berhubungan dengan konsumsi pangan pada kelompok etnis tertentu yang hidup wilayah tersebut. Untuk mengetahui besarnya variasi yang tidak dapat dihitung dari perbedaan ekologi antar wilayah, beberapa konsep sosial ekonomi turut dimasukkan. Hal ini dilakukan untuk memudahkan penggolongan wilayah ekologi seperti menjadi daerah perkotaan dan pedesaan. Dalam analisis multivariat pangan, variabel wilayah pedesaan dan perkotaan dimasukkan sebagai variabel dummy agar dapat mencakup beberapa perbedaan variasi ekologi (yang tidak dapat dihitung) seperti pada variasi wilayah dan kelompok etnis (Lee, 1987; Adrian \& Daniel, 1976; Reynolds, 1990; MacMillan et al., 1972).

Keragaman konsumsi pangan dapat dipengaruhi oleh preferensi pangan yang ditentukan oleh nilai-nilai kebiasaan/adat (tradisi dan kepercayaan) yang berhubungan dengan pangan, pengetahuan gizi dan kualitas pangan. Walaupun beberapa jenis pangan tertentu seringkali digantikan dengan pangan lain yang kandungan gizinya serupa. Konsekuensinya, preferensi pangan mungkin berhubungan dengan keragaman konsumsi pangan seperti yang telah diperhitungkan dari keragaman konsumsi pangan sejenis tetapi tidak dengan keragaman konsumsi pangan seperti yang telah diperhitungkan dari sebagian besar kelompok pangan. Sebagai tambahan, jika jenis pangan yang tersedia di seluruh wilayah sama, maka akan sulit untuk memasukkan jenis pangan yang tersedia sebagai salah satu determinan keragaman konsumsi pangan.

\section{Besar dan Komposisi Rumahtangga}

Model analisis yang umum pada determinan konsumsi pangan biasanya menggunakan ukuran rumahtangga, pendapatan atau pengeluaran dan harga sebagai faktor determinan yang mungkin (Buce, 1987; Raunikar, \& Huang, 1987). Umumnya, pada rumahtanggarumahtangga dengan tingkat pendapatan yang sama, total konsumsi pangan rumahtangga meningkat seiring dengan peningkatan jumlah anggota rumahtangganya (Adrian \& Daniel, 1976; Worsley, 1991; Longhurst, 1984; Blanciforti et al., 1981). Pendapatan yang terbatas pada rumahtangga berukuran besar akan mengakibatkan jenis pangan yang dikonsumsi jadi kurang bervariasi dan memiliki kualitas gizi yang lebih rendah jika dibandingkan dengan rumahtangga yang berukuran lebih kecil (Dewey, 1981 ; Fleuret $P$ \& Fleuret A, 1980). Horton mensimulasikan sebuah model ekonometrik dengan menggunakan data
Gujarat untuk menganalisis dampak ukuran rumahtangga terhadap asupan pangan. Hasilnya menunjukkan bahwa pengurangan satu anggota rumahtangga akan meningkatkan konsumsi kalori sebesar 240-400 kalori per kapita, tergantung pada umur dan jenis kelamin anggota rumahtangganya (Horton, 1985).

Preferensi pangan pada anak-anak berbeda dengan kelompok orang dewasa dan kelompok usia lanjut (Buse \& Salathe 1978). Konsumsi pangan pada kelompok anak-anak umumnya bergantung dari apa yang diberikan oleh ibu atau orangtuanya (Abraham 1988; Blanciforti et al. 1981; Horton 1985; Buse \& Salathe 1978) yang tentunya berbeda dengan yang diberikan untuk kelompok remaja atau dewasa. Kelompok remaja dan dewasa lebih suka untuk memilih pangan yang dikonsumsinya sendiri dan pada kelompok remaja biasanya kurang begitu peduli dengan kandungan gizi yang tinggi pada pangan dan mereka cenderung lebih menyukai pangan yang sedang populer (Blanciforti et al. 1981; Rappoport et al. 1992; Kelly 1981; Woodward 1985).

Penelitian yang dilakukan di USA dan UK menunjukkan bahwa wanita berpendapatan tinggi lebih sedikit mengonsumsi pangan sumber kalori dan lebih banyak mengonsumsi sayur dan buah daripada pria karena faktor body image dan kesadaran untuk hidup sehat. (Wandel 1994; Rappoport et al. 1992). Rappoport et al. (1992) menyimpulkan bahwa alasan penting untuk mengonsumsi pangan tertentu bagi wanita berpendapatan tinggi di Kansas adalah karena pertimbangan gizi dan kesehatan. Hasil penelitian tersebut konsisten dengan teori Maslow mengenai tingkatan yang lebih tinggi dari kebutuhan motivasi perilaku manusia. Pendidikan dan pendapatan yang lebih tinggi akan mendorong manusia untuk lebih perhatian terhadap kesehatannya (Maslow 1970). Hal tersebut mendorong mereka untuk mengonsumsi beragam jenis pangan dengan porsi pangan sumber kalori yang lebih kecil. Sementara itu, kelompok usia lanjut di USA dan Australia, khususnya yang tinggal di daerah perkotaan, lebih menghargai kesehatannya (Blanciforti et al. 1981; Rappoport et al. 1992; Crawford \& Baghurst 1990; Slesinger et al. 1980) yang akhirnya mendorong mereka untuk mengonsumsi beragam jenis pangan. Berdasarkan hal tersebut, kami mengajukan suatu hipotesis bahwa perbedaan konsumsi pangan berhubungan dengan jenis kelamin dan tahapan dalam siklus hidup.

Beberapa penelitian tentang keragaman konsumsi pangan turut mempertimbangkan 
ukuran dan komposisi rumahtangga dalam analisisnya karena setiap rumah tangga memiliki ukuran dan komposisi yang berbeda. Caliendo et al. (1977) dan Schorr et al. (1972) (menggunakan analisis bivariat) melaporkan bahwa tidak ada hubungan yang signifikan antara usia anak-anak dengan keragaman konsumsi pangan mereka atau antara jenis kelamin anak-anak dengan keragaman konsumsi pangannya (Tabel 1). Sampel pada penelitian yang pertama adalah anak-anak prasekolah, yang berusia antara 1 sampai 4 tahun (Caliendo et al. (1977) dan sampel penelitian kedua adalah remaja dengan rentang usia antara 7 sampai 12 tahun (Schorr et al. 1972). Karena sampel tidak mencakup seluruh rentang usia (tahapan siklus hidup), maka hubungan antara usia dan keragaman konsumsi pangan tidak dapat dianalisis dengan lebih teliti.

Ukuran keragaman konsumsi pangan yang digunakan pada penelitian lain yang menggunakan data nasional dengan bermacam-macam kelompok usia di Amerika (Lee \& Brown 1989; Lee 1987), menunjukkan bukti yang konsisten bahwa kelompok umur dan jenis kelamin merupakan determinan keragaman konsumsi pangan setelah dikontrol dengan biaya pangan. Ukuran rumahtangga mempunyai hubungan yang berkebalikan dengan keragaman konsumsi pangan. Lee dan Brown (1989) menunjukkan bahwa penambahan satu orang anggota rumahtangga pada rumahtangga yang terdiri atas dua orang akan berdampak lebih besar terhadap keragaman konsumsi pangannya dibandingkan penambahan jumlah anggota yang sama pada rumahtangga yang terdiri atas empat orang.

Oleh karena itu, jumlah anggota rumahtangga dan komposisinya merupakan faktor yang diduga sebagai determinan keragaman konsumsi pangan di Indonesia. Variasi pada komposisi rumahtangga juga turut mencerminkan variasi dalam preferensi pangan dan unit konsumennya di rumahtangga. Hal ini dapat diidentifikasi, termasuk pada variabel kelompok umur dan jenis kelamin yang digunakan untuk analisis determinan keragaman konsumsi pangan.

Berkaitan dengan unit konsumen rumahtangga dalam analisis pendapatan dan data asupan pangan di tingkat rumahtangga, Para ahli ekonomi menyarankan untuk menggunakan unit dewasa yang ekuivalen (Prais \& Huothaker 1955; Price 1970; Deaton \& Meullbauer 1980). Unit dewasa yang ekuivalen lebih tepat daripada unit per capita karena hal tersebut diperbolehkan untuk data rumahtangga yang memiliki perbedaan ukuran dan perbedaan komposisi umur dan jenis kelamin. Dengan kata lain, hal itu merupakan ukuran serta komposisi (umur dan jenis kelamin) rumahtangga yang standar. Saat ini, para ahli gizi (J us' at 1991; Chen et al. 1990; Hardinsyah 1990) dan para ahli ekonomi (Popkin 1980; Balnciforti et al. 1981; Trairatvorakul 1984; Braun et al. 1989) telah menerapkan penggunaan unit dewasa pria ekuivalen berdasarkan kebutuhan kalori untuk analisis variabel ekonomi dan gizi pada tingkat rumahtangga.

Singkatnya, review dari berbagai literatur ini menyatakan bahwa determinan yang mungkin mempengaruhi keragaman konsumsi pangan di tingkat rumahtangga mencakup pengetahuan gizi, daya beli pangan, waktu yang tersedia bagi ibu untuk pengelolaan pangan, preferensi pangan dan ketersediaan pangan. Setiap faktor tersebut kemungkinan ditentukan oleh berbagai faktor sosial demografi, faktor ekonomi dan faktor lainnya. Faktor sosial demografi yang dimaksud adalah pendidikan, paparan media massa, status dan jenis pekerjaan ibu, komposisi dan ukuran rumahtangga, sedangkan faktor ekonominya seperti biaya pangan, pendapatan dan harga pangan dan yang terakhir ditentukan pula oleh berbagai faktor lain seperti kepercayaan dan tradisi yang berhubungan dengan pangan, produksi dan distribusi pangan.

\section{Diagram Pohon Faktor Determinan}

Berdasarkan review yang telah dipaparkan di bagian sebelumnya, maka dapat disusun suatu diagram pohon dari faktor-faktor yang diduga sebagai determinan dari keragaman konsumsi pangan. Ada lima faktor yang diduga merupakan determinan penting keragaman konsumsi pangan yaitu daya beli pangan, pengetahuan gizi, waktu yang tersedia untuk pengelolaan pangan, kesukaan pangan dan ketersediaan pangan (gambar 2.1). Dengan menggunakan prinsip metode formulasi kerangka pikir, yang diusulkan oleh Delp et al. (1977), maka diagram pohon yang dikembangkan untuk menggambarkan kerangka pikir keragaman konsumsi pangan ditunjukkan pada gambar 1.

Variabel yang diduga merubah daya beli pangan adalah biaya pangan, harga pangan dan ukuran rumahtangga. Biaya pangan kemungkinan dipengaruhi oleh pendapatan rumahtangga, komposisi rumahtangga da pengetahuan gizi orang tua, khususnya ibu. Harga pangan kemungkinan dipengaruhi oleh kuali- 
tas pangan, penawaran (ketersediaan) pangan dan penawaran pangan.

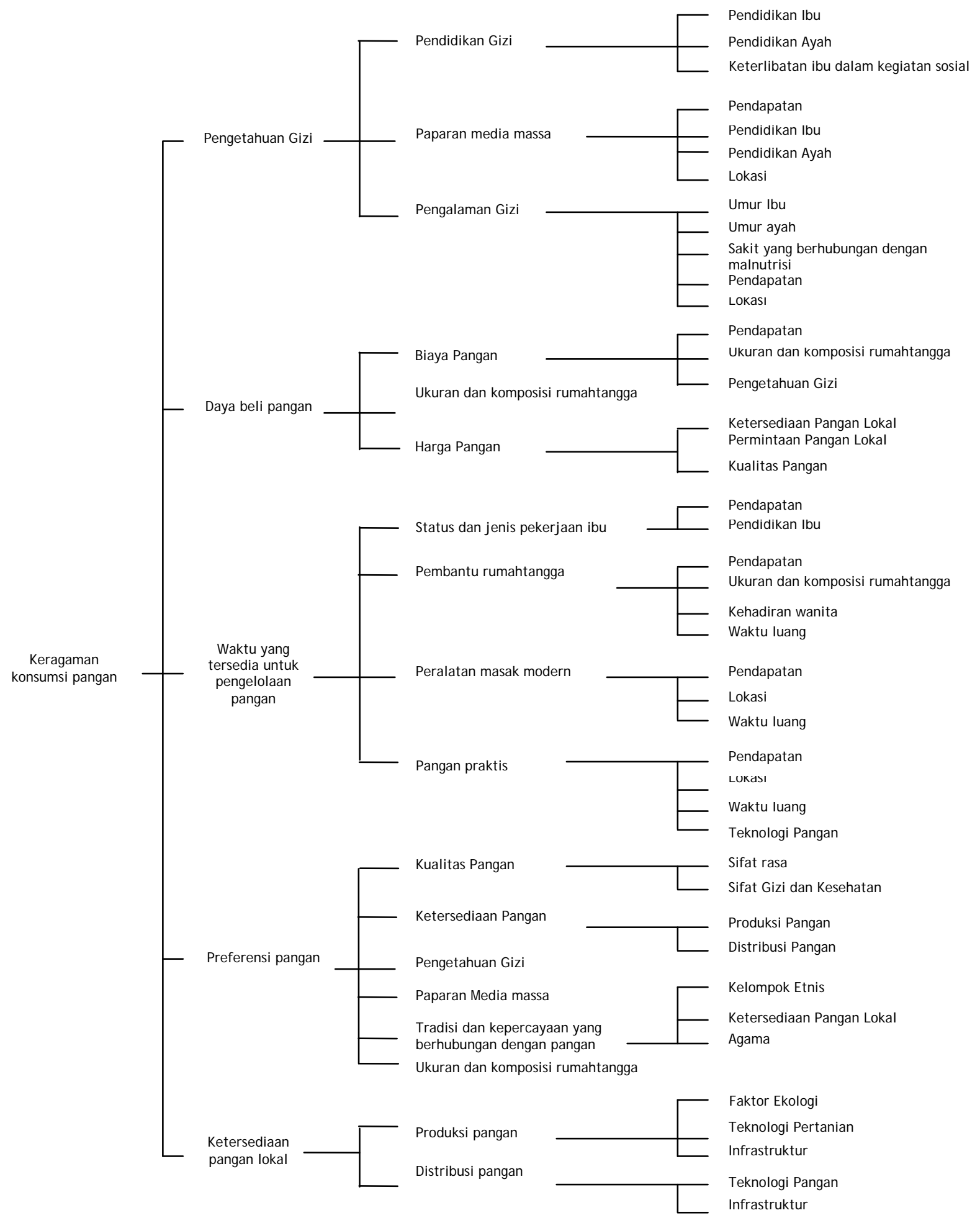

Gambar 1. Diagram Pohon Faktor yang Diduga sebagai Determinan Keragaman Konsumsi Pangan

Variabel yang diduga merubah pengetahuan gizi adalah pendidikan gizi, yang kemungkinan dipengaruhi tingkat pendidikan kedua orang tua, dan partisipasi ibu dalam kegiatan sosial. Paparan media massa pada anggota rumahtangga kemungkinan dipenga- 
ruhi oleh pendapatan rumahtangga, tingkat pendidikan formal kedua orang tua, lokasi tempat tinggal (apakah di desa atau kota) dan pengalaman gizi anggota rumahtangga. Pengalaman ini dipengaruhi oleh usia kedua orang tua, pengalaman sakit yang terkait dengan malnutrisi, pendapatan rumahtangga, dan lokasi tempat tinggal.

Waktu yang dialokasikan oleh wanita untuk pengelolaan pangan ditentukan oleh status dan jenis pekerjaan ibu, kehadiran pembantu rumahtangga, ketersediaan peralatan masak modern (kompor gas atau listrik, oven, microwave dan lemari pendingin) dan ketersediaan bahan pangan yang praktis (siap santap/siap saji), yang akan dapat mempersingkat waktu penyiapan pangan. Status dan jenis pekerjaan ibu kemungkinan dipengaruhi oleh pendapatan rumahtangga dan tingkat pendidikan ibu. Sedangkan kehadiran pembantu di rumahtangga kemungkinan dipengaruhi oleh pendapatan rumahtangga, jumlah wanita yang dapat membantu untuk memasak, komposisi rumahtangga dan waktu luang atau istirahat yang diinginkan oleh ibu. Ketersediaan peralatan masak modern dan pangan yang praktis (siap masak/ siap saji) dipengaruhi oleh pendapatan, lokasi tempat tinggal, dan teknologi.

\section{DAFTAR PUSTAKA}

Abraham S. 1988. What does food mean to young Australian women. In: Truswell AS, Wahlqvist ML. Food habits in Australia, Proceeding of the first Deakin/Sydney Universities Symposium on Australian Nutrition, 85-93.

Adrian J, Daniel R. 1976. Impact of socioekonomic factors on consumption of selected food nutrients in the United States. American J ournal of Agriculture Ekonomics, 58, 31-38.

Atkinson AB. 1975. The ekonomics of Inequality. Clarendon Press, Oxford, 1-295.

Bairagi R. 1980. Is income the only constraint on child nutrition in rural Bangladesh ? Bulletin of the World Health Organization, 58,767-772.

Becker GS. 1965. A theory of the allocation of time. Economics J ournal, 75, 493-517.

Behrman JR, Deolalikar AB, Wolfe BL. 1988. Nutrients: Impact and determinants. The
World Bank Ekonomic Review, 2,299319.

Behrman JR, Wolfe BL. 1982. How does Mother's schooling affect family health, nutrition, medical care usage, and household sanitation ? J ournal of Econometrics, 36, 185-204.

Blanciforti L, Green R, Lane S. 1981. Income and expenditure for relatively more versus relatively less nutritious food over the life cycle. American Journal of Agricultural Economics, 63,255-260.

Bouis HE. 1989. The determinants of household-level demand for micronutrients: an analysis for Philippine farm household. Final report submitted to the World Bank, Population, Health and Nutrition Division. International Food Policy Research Institute, Washington DC, 1-68.

Bouis HE. 1990. Evaluating demand for calories for urban and rural populations in the Philippines: Implications for nutrition policy under ekonomic recovery. World Development, 18,281-299.

Braun JV, Puetz D, Webb P. 1989. Irrigation technology and commercialization of rice in the Gambia: Effects on income and nutrition. International Food Policy Research Institute, 75, 1-68.

Buce RC. 1987. Socioeconomic, demographic and psychological variables in demand analysis. In: Raunikar R, Huang C-L, eds. Food demand analysis: Problems, issues and empirical evidence. Iowa University Press, Ames, lowa, 186-215.

Burnett S-A, Rees AM. 1991. Advantages and disadvantages associated with the increased use of microwave energy in food preparation. Journal of Consumer Studies and Home Ekonomics, 15,231239.

Burns C, McGeorge D, caterson ID. 1988. Nutriton Knowledge and practice in an obese population. In. Trusswell AS, Wahlqvist $L$, eds. Proceeding of the First Deakin/ Sydney University Symposium on Australian Nutrition. North Balwyn: R Gordon, 1-421. 
Buse RC, Salathe LE. 1978. Adult equivalent scales: An alternative approach. American J ournal of Agricultural Economics, 60,460-468.

Caliendo MA, Sanjur D, Wright J , Cummings G. 1977. Nutritional status of preschool children. Journal of the American Dietetic Association, 71,21-25.

Campbell ML, Sanjur D. 1992. Single employed mother and preschool child nutrition - an ecological analysis. Journal of Nutrition Education, 24,67-74.

Central Bureau of Statistics. 1992. Expenditure for consumption of Indonesia 1990, Book I. Central Bureau of Statistics, Jakarta, 1-195

Chatterjee M. 1989. Socio-economic and sociocultural influences on women's nutritional status and roles. In: Gopalan C, Kaur $\mathrm{S}$, eds. Women and nutrition in India. Nutrition Foundation of India, New Delhi, 296-323.

Chen J , Campbell TC, Li J, Peto R. 1990. Diet lifestyle and mortality in China: A study of the Characteristic of 65 Chinese counties. Oxford, UK: J oint publication of Oxford University Press, Cornell University Press and China People's Publishing House, 1-894.

Choudry M, Jain S, Saini V. 1986. Nutritional status of children of working mothers. Indian Pediatrics, 23, 267-270

Cohen D. 1981. Consumer behavior. Random House Business Division, New York, 1504.

Cooper D. In: Cooper D, Vellve R, Hobbelink H, eds. Growing diversity: Genetic resources and local food security. Intermediate Technology Publication, Barcelona, 1-16.

Crawford DA, Baghurst KI. 1990. Diet and health: A national survey of beliefs, behaviors and barriers to change in the community. Australian Journal of Nutrition and Dietetics, 47,97-104.

Deaton A, Muellbauear. 1980. Economics and concumer behavior. Cambridge University Press, Cambridge, 1-450.
Delp P, Thesen A, Motiwalla, Seshadri N. 1977. Systems tools for project planning. International Development Institute, Indiana, 1-112.

Den Hartog AP. 1983. Evaluation of nutrition education: assessment of the social context. In: Schuch B, ed. Evaluation of nutrition education in third world communities. Hans Huber Publishers Bern, Vienna, 45-55. (Nestle Foundation Publication Series, vol 3).

Dewey KG. 1980. The impact of agricultural development on child nutrition in Tabasco, Mexico. Medical Anthropology, $4,21-54$

Dewey KG. 1981. Nutritional consequences of transformation from subsistence to commercial agriculture. Human Ecology, 9, 151-187.

Ellis J, Wiens J, Rodel C, Anway J. 1976. A conceptual model of diet selection as an ecosystem process. J ournal of Theoretical Biology, 60,93-108.

Eschleman MM. 1991. Introductory nutrition and diet therapy. J B Lippincot Company, Philadelphia, 1-664.

Fleuret P, Fleuret A. 1980. Nutrition consumption, and agricultural change. Human Organization, 39, 250-260.

Food and Agriculture Organization. 1987. Women in African food production and food security. In: Gittinger J P, Leslie J, Hoisington $\mathrm{C}$, eds. Food policy: Integrating supply, distribution, and consumption. The J ohn Hopkins University Press, Baltimore, 133-140.

Foster P. 1992. The world food problem: Tackling the causes of undernutrition in the third world. Lynne Rienner Publishers, Boulder, 1-367.

Giese J. 1994. Modern alchemy: use of flavors in food. Food Technology, 106-116.

Gofton L, Ness M. 1991. Twin trends: health and convenience in food change or who killed the lazy housewife. British Food J ournal, 93, 17-23.

Goldfarb SM. 1985. Nutrition knowledge, attitudes and practices of runners 
[Master Thesis]. Institute of Health Professions, USA, 2,S11-S35.

Goungetas BP, J ensen HH, Johnson SR. 1993. Food demand projections using full demand systems. Food Policy, 18,55-63

Hardinsyah. 1990. Seasonal variation of household vitamin $A$ and iron availability based on food security data in Indonesia. Unpublished report to Cornell Food and Nutrition Policy Program (CFNPP)-Cornell University. Ithaca-NY, 1-24.

Hardinsyah. 1996. Measurement and determinants of food diversity: Implications for Indonesia's food and nutrition policy. Nutrition Program, Medical School, University of Queensland.

Hardinsyah, Heywood PF, 1993. Review of the association between food diversity and diet quality. Abstract of the XV International Congress of Nutrition, Adelaide.

Hardinsyah, Mark GC, 1996. Dietary diversity and nutrition related health outcomes: $A$ Review. Abstract of the XII International Congress of Dietetics, Manila.

Harvey PW \& Heywood PF. 1983. Twenty-five years of dietary change in Simbu Province, Papua New Guinea. Ecology of Food and Nutrition, 13,27-35

Helman CG. Culture, health and illness, an introduction for health professionals. Wright, London, 1-344.

Hickman BW, Gates GE, Dowdy RP. Nutrition claims in advertising: a study of four women's magazine. Journal of Nutrition Education, 25,227-235.

Horton S. 1985. The determinants of nutrient intake, result from Western India. Journal of Development Economics, 19, 147-162.

Horton S, Campbell. 1991. Wife's employment, food expenditure, and apparent nutrient intake: Evidence from Canada. American Journal of Agricultural Economics, 73, 784-794.

Huffman SL. 1987. Women's activities and impacts on child nutrition. In: Gittinger $P$, Leslie J. Hoisington C, eds. Food policy, integrating supply, distribution and consumption. The John Hopkins University Press, Baltimore, 371-384.

Immink MDC. 1982. Purchasing power and food consumption behavior. In: Sanjur D, ed. Social and cultural perspectives in nutrition. Prentice Hall Inc, Englewood Cliffs, NY, 91-122.

Iwao S. 1993. The Japanese women, the traditional image and changing reality. The Free Press, a Division of Macmillan Inc, New York, 1-304.

Jacobs BL. 1981. Communication content of nutrition information in selected popular print media [Master Thesis]. Michigan State University, Michigan, 1-190.

Johnson DW, Johnson RT. 1985. A meta analysis and synthesis of nutrition education research. Journal of Nutrition Education, 1-67.

Jus'at I. 1991. Determinants of nutritional status of preschool children in Indonesia: An analysis of national socio-ekonomic survey (SUSENAS), 1987 [Dissertation]. Faculty of the Graduate School of Cornell University, Ithaca, NY, 1-214.

Kant AK, Block G, Schatzkin A, Ziegler RG, Nestle M. 1991. Dietary diversity in the US population, NHANES II 1976-1980. Journal of the American Dietetic Association, 91, 1526-1531.

Kant AK, Schatzkin A, Harris TB, Ziegler RG, Block G, 1993. Dietary diversity and subsequent mortality in the first National Health and Nutrition Examination Survey Epidemiologic Follow Up Study. The American Journal Clinical Nutrition, 57,434-440.

Kantor Menteri Koordinator Kesejahteraan Rakyat (Walfare Ministry). 1989. Pola umum perbaikan menu makanan rakyat (General guideline for the improvement of people's diet). Kantor Menteri Koordinator Kesejahteraan Rakyat, Jakarta, $1-26$

Kapka-Schutt, Mitchell ME. Positive effect of a nutrition instruction model on a dietary behavior of a selected group of elderly. J ournal of Nutrition for Elderly, 12,2953. 
Kelly AC. 1981. Demographic impact on demand patterns in the low income setting. Economic Development and Cultural Change, 30,1-16.

Kirk M, Gillespie AH. 1990. Factors affecting food choices of working mothers with young families. Journal of Nutrition Education, 22, 161-168.

Lang T. 1992. Food policy and public health. Public Health, 106, 91-125.

Lee J, Brown MG. 1989. Consumer demand for food diversity. Southern J ournal of Agricultural Economics, 21,47-53.

Lee J-Y. 1987. The demand for food varied diet with econometric models for count data. American Journal of Agriculture Economics, 69,687-692.

Leibowitz A. 1974. Education and home production. The American Ekonomic Review, 74,243-251.

Leonard WR \& Thomas RB. 1988. Changing dietary patterns in the Peruvian Andes. Ecology of Food and Nutrition, 21,245263.

Longhurst R. 1984. Agricultural production and food consumption: Some neglected linkages. Food and Nutrition, 9,2-5.

MacMillan JA, Tung F-L, Loyns RMA. 1972. Differences in regional household consumption patterns by urbanization: A cross-section analysis. J ournal of Regional Sciences, 12,417-424.

Lyman B. 1989. A psychology of food. Van Nostrand Renhold Company, New York, 1-189.

Mann CK, Huddleston B. 1987. Introduction and summary. In: Mann CK, Huddleston B, eds. Food policy, framework for analysis and action. Indiana University Press, Bloomington, 1-13.

Maslow AH. 1970. Motivation and personality. Harper and Row, New York, 1-369.

McGuire J , Popkin BM. 1989. Beating the zerosum game: Women and nutrition in the third world. Part I. Food and Nutrition Bulletin, 11, 38-63
Megawangi R. 1991. Preschool aged nutritional status parameters for Indonesia, and their application to nutrition-related policies [Dissertation]. The School of Nutrition, Tuft university, Boston, 1-214.

Miller DT. 1990. The impact of mothers' employment on the family meal. Journal of Home Ekonomics, 82, 25-26.

Moore H, Svetkey L, Lin P-H, Karanja N, Jenkins $M, 2002$. The DASH Diet for Hypertension. The Free Press, New York.

National Board for Family Planning (BKKBN) and Community Systems Foundation. 1986. KB-Gizi - An Indonesian integrated family planning, nutrition and health program: The Evaluation of the first five years of program implementation in East Java and Bali. BKKBN and community Systems Foundation, Ann Arbor, Michigan, 1-269.

Per-Andersen P. An analytical framework for assessing nutrition effects of policies and programs. In: Mann CK, Huddleston B, eds. Food Policy, framework for analysis and action. Indiana University Press, Bloomington, 55-79.

Pinstrup-Andersen P. 1985. Food prices and the poor in developing countries. European Journal of Agricultural Economics, 12,69-81.

Pinstrup-Andersen P, Caicedo E. 1978. The potential impact of changes in income distribution on food demand and human nutrition. American Journal of Agricultural Economics, 60,402-415.

Pinstrup-Andersen P, de Londono NR, Hoover E. The impact of increasing food supply on human nutrition: Implications for commodity priorities in agricultural research policy. American Journal of Agricultural Economics, 58, 131-142.

Pitt MM, Rosenzweig MR. 1985. Health and nutrient consumption across and within farm household. The review of ekonomics and statistics, 67,213-223.

Popkin BM. 1980. Time allocation of the mother and child nutrition. Ecology of Food and Nutrition, 9, 1-9. 
Prais SJ, Houthake HS. 1955. The analysis of family budget. Cambridge University Press, London, 1-372.

Price DW. 1970. Unit equivalent scale for specific food commodities. American Journal of Agricultural Economics, $52,224-233$.

Rahman A. 1980. Muhammad the educator of mankind. The Muslim School Trust, London, 1-473.

Ramington. 1948. In: Young PT. Appetite, palatability and feeding habit: A critical review. Psychological Bulletin, 45,289318.

Randall E. 1982. Food preferences as a determinant of food behavior. In: Sanjur $D$, ed. Social and cultural perspectives in nutrition. Prentice Hall Inc., Englewood Cliffs, NY, 123-145.

Rappoport LH, Peters GR, Huff-Corzine, Downey RG. 1992. Reasons for eating: An explanatory cognitive analysis. Ecology of Food and Nutrition, 28, 171-189.

Raunikar R, Huang C-L. 1987. Food demand analysis: Problems, issues and empirical evidence. lowa University Press, Ames, lowa, ix-xiii.

Ravallion M. 1992. Does undernutrition respond to incomes and prices ? Dominance tests for Indonesia. The World Bank Ekonomic Review, 6,109124.

Reaburn J A, Krondl M, Lau D. 1974. Social determinants in food selection. Journal of the American Dietetic Association, 74,637-641.

Renner HD. 1944. The origin of food habits. Faber and Faber Ltd., London, 1-261.

Reynolds A. 1990. Analyzing fresh vegetables consumption from household survey data. Southern Journal of Agricultural Economics, 22,31-38.

Robinson C. 1968. Fundamentals of normal nutrition. The Macmillan Company, New York, 1-665.
Rosenzweig, MR. 1986. Birth spacing and sibling inequality: Asymetric information within the family. International Economic Review, 27,55-76

Sayogyo. 1990. Women's integration in rural development and women's reproductive behavior. Center for Development Studies, Research Institute of Bogor Agricultural University, for Food and Agriculture Organization of the United Nations, Bogor, 1-104.

Sayogyo P. 1989. Pengambilan keputusan dalam menentukan pola makan keluarga (The decision making on foods). In: Sastrapradja S, Muhilal, eds. Proceeding Widyakarya Nasional Pangan dan Gizi IV (The Fourth National Food and Nutrition Workshop). LIPI, J akarta, 461-475.

Schafer E, Schafer RB, Bultena GL, Hoiberg EO. 1993. Safety of the US food supply: Consumers concerns and behavior. J ournal of Consumer Studies and Home Economics. 17, 137-144.

Schorr BC, Sanjur D, Erickson EC. 1972. Teenage food habits. J ournal of the American Dietetic Association, 61,415-421.

Shah CH. 1983. Food preference, poverty, and the nutrition gap. Economic Development and Cultural Change, 32,121-141.

Sigit H. 1985. Income distribution and household characteristics. Bulletin of Indonesian Ekonomic Studies, 21,51-68.

Slesinger DP, McDivitt M, O'Donnell FM. 1980. Food patterns in an urban population: Age and sociodemographic correlates. J ournal of Gerontology, 35,432-441.

Soper J, Carpenter RA, Shannon BM. 1992. Nutrition knowledge of aerobic dance instructors. J ournal of Nutrition Education, 24,59-66.

Syarief $\mathrm{H}$, Madanijah S, Hardinsyah, Pranadji DK. 1988. Model pendidikan gizi bagi sekolah dasar (A nutrition education model for primary school students). Pusat Antar Universitas, Institut Pertanian Bogor, Bogor, 1-120.

Timmer PC, Alderman H. estimating consumption parameters for food policy ana- 
Iysis. American Journal of Agricultural Economic, 61, 982-994.

Trairatvorakul P. 1984. The effect on income distribution and nutrition of alternative rice price policies in Thailand. International Food Policy Reasearch Institute, 46, 1-82.

Trichopoulou A, Kouris-Blazos, Wahlqvist, ML, 1996. Diet and overall survival in erderly people. British Medical Journal, 311,1457-1460.

Tyrell TJ, Mount TD. 1987. Analysis of food and other expenditures using a linear logit model. In: Raunikar R, Huang C-L. Food demand analysis: Problem, issues and empirical evidence. lowa University Press, Ames, lowa, 143-153.

Van de Walle D. 1988. On the use of SUSENAS for modelling consumer behavior. Bulletin of Indonesian Ekonomic Studies 24, 107-122.

Wahlqvist ML. 1988. Australian eating patterns. In: Wahlqvist ML, ed. Food and nutrition in Australia. Thomas Nelson, Canberra, 30-47.

Wandel M. 1994. Understanding Consumer concern about food-related health risks. British Food J ournal, 96, 35-40.
Williams SR. 1992. Basic nutrition and diet therapy. Moby Year Book, St. Louis, 1486.

Wolfe BL, Behrman JR. 1982. Is income overated in determining adequate nutrition ? Economic Development and Cultural Change, 31,525-549.

Woodward DR. 1985. Teenagers and their food: The effects of physical behavior and socioekonomic characteristics on intake of five food categories in Tasmania. J ournal of Food and Nutrition, 42, 7-12.

World Bank. 1993. World development report: investing in health, executive summary. Oxford University Press, Oxford, 1-23.

Worsley A. 1991. Mothers, work and food consumption: Going out to to work changes mother's diets ? Ecology of Food and Nutrition, 25,59-69.

Zeitlin MF, Megawangi R, Kramer EM, Colletta ND, Babatunde ED, Garman D. 1992. Strengthening the family to participate in development. Medford, MA: Academy for Educational Development, 1-122.

Zhi-chien H. 1993. Principles of diet therapy in ancient Chinese medicine. Asia Pacific Journal of Clinical Nutrition, 2,91-95. 